\title{
Stability Improvement of Immobilized $\alpha$-amylase using Nano Pore Zeolite
}

\author{
Maedeh Talebi ${ }^{1}$, Sedigheh Vaezifar ${ }^{2 *}$, Fariba Jafary ${ }^{3}$, Mohamad Fazilati ${ }^{4}$, Shima Motamedi 5 \\ ${ }^{1}$ Department of Biology, Science and Research Branch, Islamic Azad University, Tehran, Iran \\ ${ }^{2}$ Department of Medical Engineering, Payame Noor University, Tehran, Iran \\ ${ }^{3}$ Young Researchers and Elite Club, Falavarjan Branch, Islamic Azad University, Isfahan, Iran \\ ${ }^{4}$ Department of Biochemistry, Payame Noor University, Isfahan, Iran \\ ${ }^{5}$ School of Veterinary Medicine, Razi University, Kermanshah, Iran
}

${ }^{*}$ Corresponding author: Sedigheh Vaezifar, Department of Medical Engineering, Payame Noor University, Iran. Tel: +98-3133521803 (291), Fax: +983133521802, E-mail: vaezifar@es.isfpnu.ac.ir

Received: July 13, 2015; Revised: October 10, 2015; Accepted: January 12, 2016

\begin{abstract}
Background: Enzyme engineering by immobilization techniques has proven to be well compatible with the other chemical or biological approaches aiming to improve enzyme's functions and stability. Zeolites are porous alumino-silicates with a wide range of porosity and particle size along with the other remarkable properties such as high surface area, high stability against a wide range temperatures, $\mathrm{pHs}$, as well as organic solvents.

Objectives: Nano-zeolites are a class of advanced materials that have special properties that has made them ideal candidate for a wide range of applications.

Materials and Methods: In this study, a nano-zeolite which has been synthesized and characterized in our previous work, was used to immobilize $\alpha$-amylase and activated with glutaraldehyde as a bi-functional agent to improve enzyme properties.

Results: Studies have shown an increased stability of the immobilized enzyme compared to the free enzyme against a range of temperature change and $\mathrm{pHs}$ as well. Also the stability of the immobilized enzyme was increased with respect to storage. The calculated binding efficiency shows that the immobilized $\alpha$-amylase conserved $58.44 \%$ of its native activity. Conclusions: Using nano pore zeolite for covalent attachment of the $\alpha$-amylase resulted in an increased resistance of this enzyme against denaturation. The immobilized enzyme demonstrated higher stability compared to the free enzyme at higher temperatures and $\mathrm{pH}$ variations. Immobilization also caused an increase in the enzyme stability during storage.

Keywords: $\alpha$-amylase; Enzyme Immobilization; Nano pore zeolite; Stability
\end{abstract}

\section{Background}

Enzyme stability is an important issue, as it has taken a wide range of applications in a diverse field of the industries, especially in terms of application and technology. Enzyme engineering, through immobilization techniques, i.e. adsorption, multipoint, and multi subunit covalent binding, as well as entrapment, is a preferred approach for improving enzyme properties, such as, stability, specificity, activity, and inhibition by reaction products (1). Immobilized enzymes have shown to display a much better operational properties than the free enzymes in the harsh condition. This process can maintain the activity of the enzyme for a long time and allows enzyme re-application in the industrial reactors (2).

There are different organic and inorganic nano- materials that can be used as a support for enzyme immobilization to ensure the highest retention of the enzyme activity and stability (3-6).

Zeolites are porous alumino-silicates with a wide range of porosity and particle size and remarkable properties such as high surface area, high stability against variation in the temperature and $\mathrm{pH}$, in addition to organic solvents. These materials are resistant to micro-organisms and radiation respectively. They have specific properties such as ability to exchange ions, adsorption, molecular sieving, and catalysis, in addition to proper conductivity. As well, these materials are cost effective, and non-toxic with respect to the health issues. Therefore, they have found numerous applications in the recent years and can be considered as a suitable candidates for a variety of technological 
applications such as water purification and softening, separation of gases, nuclear industry, and sensors (614). They can also act as suitable supports for immobilization of enzymes (15-18). $\alpha$-amylase is among starch hydrolyzing enzymes with a wide range of applications in various industries such as textile, paper industries, detergent applications, and fermentation. Therefore, an improved operationally stable $\alpha$-amylase through immobilization would gain importance, especially with respect to economical point of view. In this study, thermal, $\mathrm{pH}$, and operational stability (multifold application) of the immobilized $\alpha$-amylase were studied and compared with the corresponding free enzyme. $\alpha$-amylase immobilized onto the nanopore zeolite according to the procedure described by Fernandes et al. (2004) (19). Glutaraldehyde was used for covalent immobilization of the enzyme which is quite simple, efficient method, and also among the most popular technologies for enzyme immobilization (20). Subsequently, the immobilized enzyme stability was studied against a range of temperature and $\mathrm{pHs}$. This would be of practical importance for further applications.

\section{Objectives}

Nano-zeolites are a class of advanced materials that have special properties that has made them ideal candidate for a wide range of applications. In this study, a nano-zeolite which has been synthesized and characterized in our previous work, was used to immobilize $\alpha$-amylase and activated with glutaraldehyde as a bifunctional agent to improve enzyme properties. Nanozeolite immobilization could be considered as an effective method for improving $\alpha$-amylase stability, and, as a suitable selection for its commercial applications on a large-scale industry.

\section{Materials and Methods}

\subsection{Synthesis of Nano Pore Zeolite}

Nano pore zeolite was synthesized according to our previous work. Briefly, Zeolite A was synthesized in three steps. In step one, clinoptilolite was dissolved in alkaline solution as the $\mathrm{Si}$ source. In step two, the Al solution was prepared from aluminum sulfate or sodiumaluminate and in the step three, the zeolite was synthesized in the hydrothermal conditions (21).

The solutions of $\mathrm{Si}$ and $\mathrm{Al}$ with specific calculated mass ratios were mixed together. Synthesis of the nano-zeolite requires a high speed mixing system. Hence, the stainless steel reactor was equipped with a homemade high shear mixer and mixing was performed at $1950 \mathrm{rpm}$. The mixture was heated at $90^{\circ} \mathrm{C}$ and stirred for $2 \mathrm{~h}$ in a stainless steel reactor equipped with a heating jacket. The synthesized nano-zeolite was filtered applying centrifuging at $4000 \mathrm{rpm}$ for 10 minutes. The product was washed, dried, and characterized by X-Ray Diffraction (XRD), X-Ray Fluorescence (XRF), Scanning Electron Microscopy (SEM), and Tunneling Electron Microscopy (TEM) techniques.

\subsection{Activation of Nano Pore Zeolite Supports}

The activation process of the nano-zeolite was performed according to the method described by Fernandes et al. (2004). A 2.5\% (V/V) glutaraldehyde solution was prepared in $0.1 \mathrm{M}$ sodium acetate buffer, pH 6.0 as a bifunctional agent. The mixture was left to react under reflux for $2 \mathrm{~h}$ at $30^{\circ} \mathrm{C}$.

\subsection{Enzyme Immobilization}

$\alpha$-amylase immobilization was carried out by adding $3.0 \mathrm{~mL}$ of an enzyme solution containing $66 \mu \mathrm{g}$ $\alpha$-amylase in $0.1 \mathrm{M}$ sodium acetate buffer, $\mathrm{pH} 6.0$, to $0.2 \mathrm{~g}$ activated zeolite particles. The mixture was slowly stirred for $4 \mathrm{~h}$ at $4^{\circ} \mathrm{C}$; the solids were separated and washed with the same buffer to extract unreacted enzyme. The obtained solids were checked for the enzyme activity.

\subsection{Enzyme Activity Assay}

Activity assay of $\alpha$-amylase was performed following to the procedure of Apar and Ozbek (2005) (22). The assay was performed at room temperature, using soluble starch as substrate and iodine solution as a stopper. $200 \mu \mathrm{L}$ of the prepared enzyme was added to $1000 \mu \mathrm{L}$ of $0.2 \%$ soluble starch in acetate buffer 50 $\mathrm{mM}, \mathrm{pH}$ 5.9. The mixture was incubated for $10 \mathrm{~min}$ at $30^{\circ} \mathrm{C}$. Subsequently, $200 \mu \mathrm{L}$ of the reaction mixture was added to $5 \mathrm{ml}$ iodine solution to stop the reaction. The absorbance was measured at $620 \mathrm{~nm}$ as a function of time for 2 min. The assay of the immobilized enzyme was carried out in the same condition, except, for preventing interruption in the reaction before doing spectrophotometric measurements, the nano-zeolite particles were separated from the reaction mixture.

\subsection{Enzyme Binding Efficiency}

Subsequent to performing immobilization under an appropriate condition, the solids were separated. The supernatant was collected, dialyzed against water, and was lyophilized. Using Bradford method, the protein 
content was determined (23) by dissolving the lyophilized sample in the sodium acetate buffer. The binding efficiency (amount of retained protein that remains active) was calculated as a ratio between the percentage of the immobilized active enzyme and the percentage of the retained protein (24). For statistically validating the obtained results, the experiments were performed three times.

\subsection{Thermal Stability of Immobilized and Free $\alpha$ - Amylase}

Thermal stability studies were carried out by suspending both of the free and immobilized enzymes in $0.1 \mathrm{M}$ acetate buffer, $\mathrm{pH} 6.0$ and incubating the mixture in water bath in varying tempratures, ranging from $25^{\circ} \mathrm{C}$ to $85^{\circ} \mathrm{C}$. Following to the incubation time, the mixture was immediately transferred into an ice bath and then tested for remaining activity.

\subsection{Storage Stability}

To determine the stability of the immobilized the enzyme during storage, the immobilized and the native enzymes were stored at $4^{\circ} \mathrm{C}$. Subsequently, aliquots were assayed for the enzyme activity according to the method described previously at regular intervals of the time.

\section{Results}

\subsection{Characterization of Nano Pore Zeolite}

Several methods such as XRD, XRF, SEM, TEM, were used to analyze the synthesized nano-zeolite. The XRD pattern of the synthesized nano-zeolite is shown in Figure 1. XRD technique has been used for the identification and quantification of zeolite A phase. Several reports are available on using XRD method for esti-

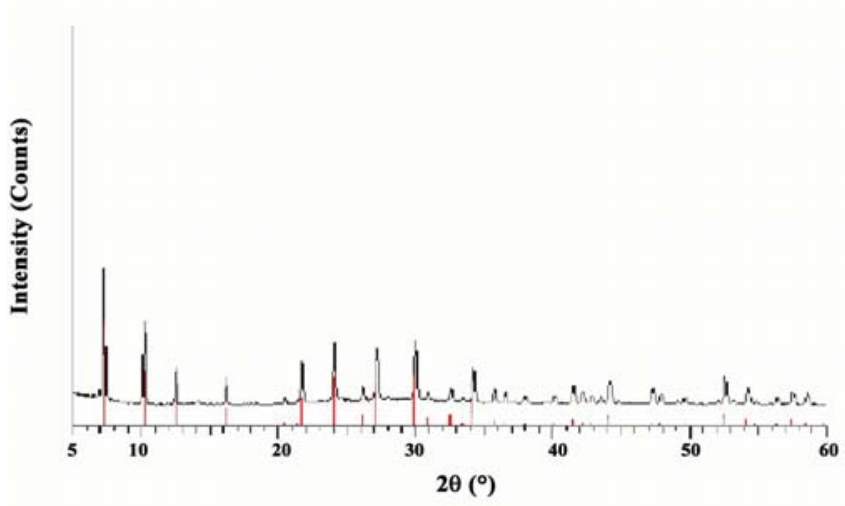

Figure 1. XRD pattern of the synthesized nano-zeolite as support of enzyme, the pattern indicates a crystalline structure of nanozeolite

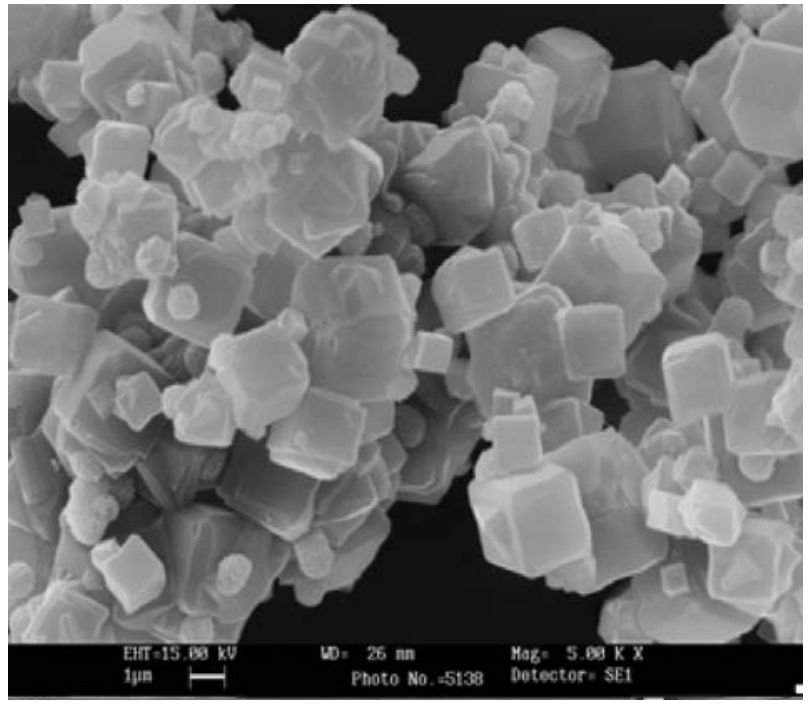

Figure 2. SEM image and morphologic structure of the nano-zeolite used as support for enzyme immobilization, the image indicates a cubic crystalline structure of the nano-zeolite particle

mating crystallinity (25). Crystallinity has been estimated for the synthesized samples according to following formula:

$\Sigma$ Relative intensities of sample $=\Sigma$ Relative intensities of standard $\times 100 \%$

The crystallinity of the synthesized nan-zeolite was $96.4 \%$, according to the Eq. (1).

SEM image of the synthesized nano-zeolite is shown in Figure 2. Cubic crystalline structure of the zeolite particle is being well seen in the SEM image. The particle size of the product can be estimated by these images, 100-200 $\mathrm{nm}$ for nano-zeolite.

TEM image of the nano-zeolite is shown in Figure 3. According to the TEM image, particle size of the nano-zeolite synthesized by a high shear mixer. The high speed mixing system has resulted in obtaining nano-zeolite particles in a size range of 100-200 nm.

\subsection{Efficiency of Enzyme Immobilization}

The amounts of the enzyme and protein linked to the nano-zeolite under the best condition for immobilization was calculated. The results show that $23.2 \%$ of the available enzyme was immobilized. This is because the surface of the support was untreated; leading to low yield. As well, $25.31 \%$ of the protein was retained.

There are several different methods of assessment for calculating the binding efficiency of $\alpha$-amylase. Colorimetric is among such methods. In this method, 


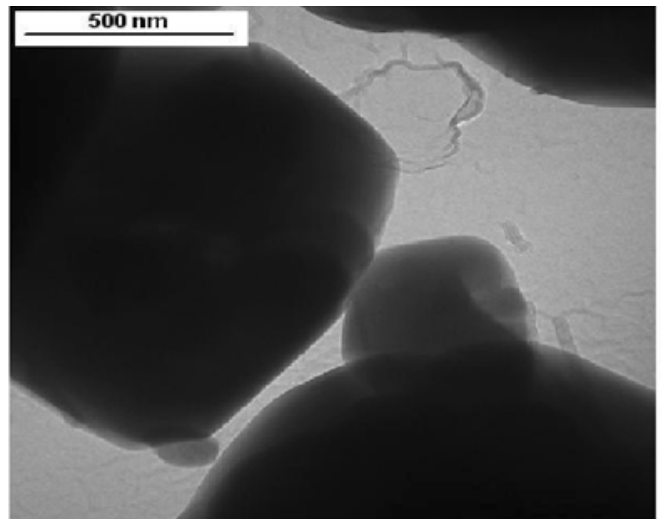

Figure 3. TEM image of the nano-zeolite as particle size determination method, the image indicates a cubical structure of the particle with high percentage of homogeneity

the absorption of enzyme solution was measured at $\lambda=280 \mathrm{~nm}$ before and after immobilization process. Binding efficiency was calculated by applying following formula:

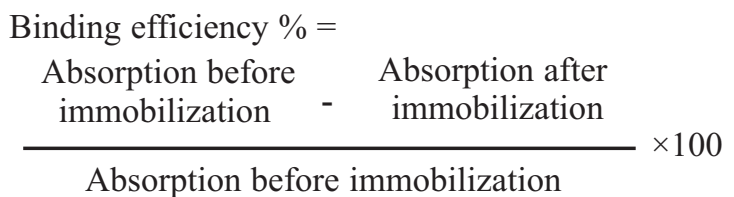

Determining the binding efficiency, it was found that $58.44 \%$ of the immobilized protein has maintained its native activity.

\subsection{Storage and Immobilized Enzyme Stability}

Assessing immobilized and free enzyme activities during storage at $4{ }^{\circ} \mathrm{C}$ has indicated that the immobilization processes has enhanced the stability of the

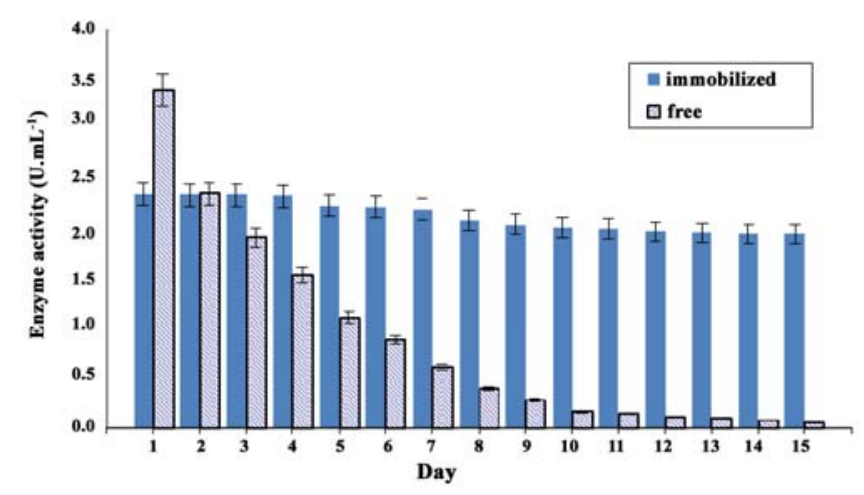

Figure 4. Storage stability of the free and the immobilized enzyme at $4{ }^{\circ} \mathrm{C}(\mathrm{n}=3)$, the graph shows the high storage stability of the immobilized enzyme compared to free enzyme during the time

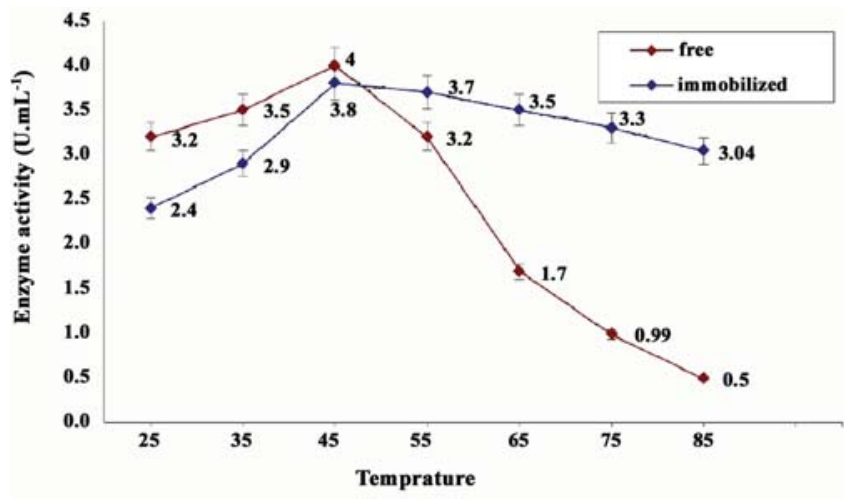

Figure 5. Thermal stability of the free $(\bullet)$ and the immobilized enzymes $(\boldsymbol{\Delta})(n=3)$. Both enzymes show a trend toward an increased enzymatic activity up to $45^{\circ} \mathrm{C}$. With further increase in the temperature, the activity of the immobilized enzyme decreases slowly, while the activity of the free enzyme decreases sharply

enzyme. The result of storage stability at $4{ }^{\circ} \mathrm{C}$ is shown in Figure 4. It should be added that when free and immobilized enzymes are stored at $4{ }^{\circ} \mathrm{C}$, the immobilized enzyme maintained $80 \%$ of its activity during 15 days of the storage, whereas, the native enzyme loses $100 \%$ of its initial activity within this period of time.

\subsection{Effect of Temperature on Free and Immobilized Enzyme Stability}

The thermal stability curves of the immobilized and free enzymes at different temperatures ranging from $25^{\circ} \mathrm{C}$ to $85^{\circ} \mathrm{C}$ are shown in (Figure 5) As could be seen the free and immobilized enzymes behave differently when exposed to the heat. The immobilized enzyme has a higher resistance against thermal denaturation compared to the free enzyme. The immobilized enzyme maintained $75 \%$ and $82 \%$ of its initial activity after $45 \mathrm{~min}$ incubation at $85^{\circ} \mathrm{C}$ and $120 \mathrm{~min}$ incubation at $75^{\circ} \mathrm{C}$, respectively. The native enzyme was absolutely inactive initially at $85^{\circ} \mathrm{C}$ and kept $10 \%$ of its activity following to $120 \mathrm{~min}$ incubation at $75^{\circ} \mathrm{C}$. It seems that multipoint attachment which are acquired in the immobilization process leading to an improved denaturation resistance of the immobilized $\alpha$-amylase.

\subsection{Effect of pH on Free and Immobilized Enzyme Activity}

The effect of the $\mathrm{pH}$ on the activity of the free and the immobilized enzymes is shown in Figure 6. As could be inferred the $\mathrm{pH}$ activity curves of the native and the immobilized enzymes are similar, particularity in the range of acidic $\mathrm{pHs}$, in addition to the optimum $\mathrm{pHs}$ for either of the studied enzymes. Both of the native and the immobilized enzymes have the maximum activ- 


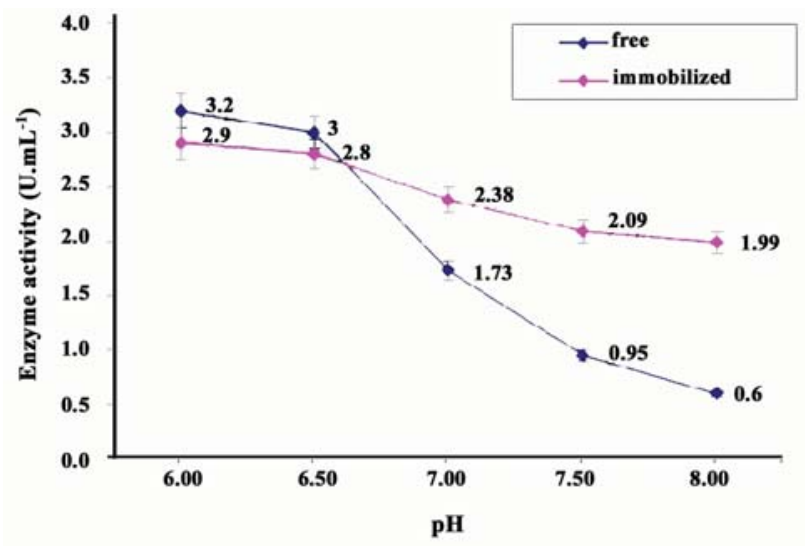

Figure 6. The $\mathrm{pH}$ stability of the free $(\bullet)$ and the immobilized enzymes $(\boldsymbol{\Delta})$. The stability of the immobilized enzyme decreases slowly up to $\mathrm{pH}$ 6.5. In contrast, the stability of the free enzyme decreases very sharply with the increased $\mathrm{pH}$

ity at $\mathrm{pH} 6$, however the immobilized enzyme presents a higher activity than that of the native enzyme in the alkaline range (pH 7.5 and $\mathrm{pH} 8.0$ ). At $\mathrm{pH} 8$ the immobilized enzyme kept $68 \%$ of its initial activity, whereas the native enzyme kept only $18 \%$ of its original activity. The observed change in the $\mathrm{pH}$ profile could be attributed to the $\mathrm{pH}$ change in the domain of the immobilized enzyme particles, resulting from nano particles characteristics.

\section{Discussion}

Due to many uses that $\alpha$-amylase has received in a wide range of the industries, the enzyme has recently been the focus of an intense researches with an aime centered on it's the stabilization process.

Swarnalatha et al. have immobilized $\alpha$-amylase using glutaraldehyde, onto magnetite nanoparticles prepared using gum acacia as the steric stabilizer. The use of this support has enabled higher immobilization of the $\alpha$ amylase $(60 \%)$, in contrast to the unmodified magnetite nanoparticles $(\sim 20 \%)$. The immobilization has also facilitated the reuse of the amylase for six cycles with $30 \%$ of loss in the initial enzyme activity (26).

Kumar et al. have used alginate as the affinity matrix for entrapment of the $\alpha$-amylase and subsequent precipitation of the beads with calcium chloride. The entrapped enzyme had higher thermal stability compared to the free enzyme. The midpoint of the thermal inactivation for the enzyme increased by $6 \pm 1^{\circ} \mathrm{C}$ upon entrapment. The reusability of the beads was dependent on the bead size and could be reused for six cycles with $\sim 30 \%$ loss in activity (27).

El-Batal et al. have studied the entrapment of the $\alpha$ - amylase onto butylacrylate-acrylic acid copolymer using gama-irradiation. Covering $\alpha$-amylase with the surfactant has made the enzyme more stable than the uncovered form of the enzyme. The results showed an increase in the relative enzyme activity with an increased degree of hydration (28).

In this research, we have studied the storage stability of the $\alpha$-amylase immobilized onto nano-zeolite as support. Results showed that the calculated binding efficiency of the immobilized $\alpha$-amylase was $58.44 \%$ of its native enzyme activity. The results suggest that the immobilization of the $\alpha$-amylase is a potentially useful approach on nano-zeolite, commercially.

\section{Conclusions}

The special properties, plus effectiveness of the nano-zeolite has made this compound to be considered as a suitable support for the enzyme immobilization. Using nano pore zeolite for covalent attachment of the $\alpha$-amylase resulted in an increased resistance of this enzyme against denaturation. The immobilized enzyme demonstrated higher stability compared to the free enzyme at higher temperatures and $\mathrm{pH}$ variations. Immobilization also caused an increase in the enzyme stability during storage.

Therefore nano-zeolite immobilization could be considered as an effective method for improving $\alpha$ amylase stability, and, as a suitable selection for its commercial applications on a large-scale industry application.

\section{Acknowledgements}

The authors would like to thank the Department of Biotechnology in Faculty of Advanced Sciences and Technologies, University of Isfahan, and Mr. Hamid Reza Dastjerd for their help during the experimental section.

\section{References}

1. Mateo C, Palomo JM, Fernandez-Lorente G, Guisan JM, Fernandez-Lafuente R. Improvement of enzyme activity, stability and selectivity via immobilization techniques. Enzyme Microb Technol. 2007;40:1451-1463. DOI: 10.1016/j.enz mictec.2007.01.018

2. Nur Royhaila M, Nur Haziqah CM, Nor Aziah B, Fahrul H, Roswanira AW. An overview of technologies for immobilization of enzymes and surface analysis techniques for immobilized enzymes. Biotechnol Biotec Eq. 2015;29:205-220. DOI: 10.1080/13102818.2015.1008192

3. Chauhan N, Narang J, Pundir CS Covalent immobilization of lipase, glycerol kinase, glycerol-3-phosphate oxidase and horseradish peroxidase onto plasticized polyvinyl chloride (PVC) strip \& its application in serum triglyceride determination. IJMR. 2014;139:603-609. 
4. Gomez JL, Bodalo A, Gomez E, Bastida J, Hidalgo AM, Gomez M. Immobilization of peroxidase on glass beads : An improved alternative for phenol removal. Enzyme Microb Technol. 2006;39:1016-1022.

5. Temocin Z, Yigitoglu M. Studies on the activity and stability of immobilized horseradish peroxidase on poly (ethylene terephthalate) grafted acrylamid fiber. Bioprocess Biosyst Eng. 2008;32:467-474. DOI: 10.1007/s 00449-008-0266-9

6. Min-Yun C, Ruey-Shin J. Activities, stabilities, and reaction kinetics of three free and chitosan-clay composite immobilized enzymes. Enzyme Microb Technol. 2005;36:75-82.

7. Auerbach SM, Carrado KA, Dutta PK. Handbook of Zeolite Science and Technology. Marcel Dekker, Inc. New York, NY, USA. 2003.

8. Cejka J., vanBekkum H., Corma A., and Schueth F. Introduction to Zeolite Molecular Sieves. $3^{\text {rd }}$ ed.; Elsevier Science: Oxford, UK, 2007

9. Cejka J, Corma A, Zones S. Zeolites and Catalysis: Synthesis, Reactions And Applications. Wiley-VCH, Germany, 2010.

10. Zheng Y, Li X, Prabir K. Exploitation of Unique Properties of Zeolites in the Development of Gas Sensors. Sensors 2012;12:5170-5194.

11. Kulprathipanja S. Zeolites in Industrial Separation and Catalysis. Wiley-VCH, Germany, 2010

12. Rhodes CJ. Properties and applications of zeolites. Sci Comput Program. 2010;93:223-284.

13. Gennaro B, Catalanotti L, Bowman RS, Mercurio M. Anion exchange selectivity of surfactant modified clinoptilolite-rich tuff for environmental remediation. J Colloid Interface Sci. 2014;15:178-183. DOI: 10.1016/j.jcis.2014.05.037

14. Maesen T, Marcus B. Introduction to zeolite sience and practice. $2^{\text {nd }}$ completely revised and expanded edition. 2009.

15. Yu T, Zhang Y, You C, Zhuang J, Wang B, Liu B, Kang Y, Tang Y. Controlled Nanozeolite-Assembled Electrode: Remarkable Enzyme-Immobilization Ability and High Sensitivity as Biosensor. Chem Eur J. 2006;12:1137-1143. DOI: 10.1002/ chem.200500562

16. Calgaroto C, Scherer RP, Calgaroto S, Vladimir Oliveira J, Oliveira D, Pergher BC. Immobilization of porcine pancreatic lipase in zeolite MCM 22 with different $\mathrm{Si} / \mathrm{Al}$ ratios. Appl Catal A-Gen. 201;394:101-104. DOI: 10.1016/j.apcata.2010. 12.032

17. Serralha FN, Lopes JM, Aires-Barros MR, Prazeres DMF, Cabral JMS, Lemos F, Ramoa Ribeiro F. Stability of a recombinant cutinase immobilized on zeolites. Enzyme Microb Technol. 2002;31:29-34. DOI: 10.1016/S0141-0229(02)00068-6

18. Phadtare S, Vinod VP, Mukhopadhyay K, Kumar A, Rao M, Raghunath V. Immobilization and biocatalytic activity of fungal protease on gold nanoparticle-loaded zeolite microspheres. Biotechnol Bioeng. 2004;85:629-637. DOI: 10.1002/bit.10856

19. Fernandes KF, Lima CS, Lopes FM, Collins CH. Properties of horseradish peroxidase immobilized onto polyaniline. Process Biochem. 2004;39:957-962. DOI: 10.1016/S00329592(03)00211-5

20. Betancor L, Lopez-Gallego F, Hidalgo A, Alonso-Morales N, Dellamora-Ortiz C, Mateo G, Fernandez-Lafuente R, Guisan J. Different mechanisms of protein immobilization on glutaraldehyde activated supports: effect of support activation and immobilization conditions. Enzyme Microb Technol. 2006;39:877-882. DOI: 10.1016/j.enzmictec.2006.01.014

21. Kamali M, Vaezifar S, Kolahduzan H, Malekpour A, Abdi MR. Synthesis of nanozeolite A from natural clinoptilolite and aluminum sulfate; Optimization of the method. Powder Technol. 2009;189:52-56. DOI: 10.1016/j.powtec.2008. 05.015

22. Apar DK, Ozbek B. Alpha-amylase inactivation during rice starch hydrolysis. Process biochem. 2005;13:1367-1379. DOI: 10.1016/S0032-9592(01)00175-3

23. Kruger NJ. Basic protein and peptide protocols: The Bradford method for protein Quantitation. Volume 32 of series methods in molecular biology. Springer Protocols, US, 1995.

24. Jafary F, Kashanian S, Samsam Sharieat Z, Omidfar K, Jafary F, Paknejad M. Stability improvement of immobilized lactoperoxidase using polyaniline polymer. Mol Biol Rep. 2012;32:10407-10412. DOI: 10.1007/s11033-012-1919-y

25. Jens W, Ulrike W, Stefan E. New aspects and trends in zeolite catalysis. Stud Surf Sci Catal. 1995;94:363-380. DOI: 10.1016/S0167-2991(06)81244-9

26. Swarnalatha V, Esther RA, Dhamodharan R. Immobilization of $\alpha$-amylase on gum acacia stabilized magnetite nanoparticles, an easily recoverable and reusable support. J Mol Catal B-Enzym. 2013;96:6-13.

27. Kumar RSS, Vishwanath KS, Singh SA, Rao AGA. Entrapment of $\alpha$-amylase in alginate beads: Single step protocol for purification and thermal stabilization. Process Biochem. 2006;41(11):2282-2288. DOI: 10.1016/j.procbio. 2006.05.028

28. El-Batal AI, Atia KS, Eid M. Stabilization of $\alpha$-amylase by using anionic surfactant during the immobilization process. Radiat Phys Chem. 2005;74(2):96-101. DOI: 10.1016/j.radphyschem.2004.12.006 